\title{
Gender Differences in Cyber and Traditional Bullying
}

Lavinia Mirela Mureșan \& Porkoláb Anamária 


\title{
Gender Differences in Cyber and Traditional Bullying
}

\author{
Lavinia Mirela Mureşan ${ }^{a^{*}}$, Porkoláb Anamária ${ }^{\mathrm{b}}$ \\ ${ }^{\text {a} D o c t o r a l ~ S c h o o l ~ „ E d u c a t i o n, ~ R e f l e c t i o n, ~ D e v e l o p m e n t ”, ~ B a b e s ̦-B o l y a i ~ U n i v e r s i t y, ~} 7$ Sindicatelor Street, 400029, Cluj-Napoca, Romania \\ ${ }^{b}$ Doctoral School University of Medicine and Pharmacy, 38 Gheorghe Marinescu street, 540139, Tîrgu Mureş, România \\ *Corresponding author: muresanlavi@yahoo.co.uk
}

Abstract

Keywords:

School violence Bullying type behavior Victimization Cyberbullying Gender role

\section{Zusammenfasung}

Schlüsselworte:

Schulische Gewalt Mobbingverhalten Veropferung Cybermobbing, Geschlechtsrolle
School violence/bullying is a complex phenomenon that exists also in school communities in Romania, especially at secondary school level, which may affect the victims for a long time, sometimes through their whole lives, through high levels of depression, anxiety or behavior problems. The phenomenon of bullying and cyberbullying is present both in girls and boys, and has a more and more alarming rate of growth. Differences between boys and girls regarding bullying/ cyberbullying have been highlighted in several studies in different countries and cultures. In this study we analyzed the manifestation of the phenomenon of bullying and cyberbullying in a gender perspective, in students of secondary schools in Mures county, based on the previous two surveys conducted among students in Mures county.

Results showed differences regarding the roles of the process of bullying, boys being harassing/ aggressive more often than girls, but significant differences in being harassed by bullying or cyberbullying were not found. The phenomenon of bullying/ cyberbullying is more and more present among secondary school students, with no major differences regarding the gender of the students.

Die schulische Gewalt ist ein komplexes Phänomen, das auch in unseren Schulgemeinden existiert, besonders in der Sekundarstufe, und das das Opfer eine sehr lange Zeit beeinflussen kann und ihm manchmal lebenslange Beschädigungen durch ein erhöhtes Depressionsniveau, Angst oder durch Verhaltensstörungen.verursachen kann.

Das Phänomen des Bullyngs/ Mobbings und des Cyberbullyings/ Cybermobbings ist sowohl bei den Mädchen als auch bei den Jungen anwesend und stellt einen alarmierenden wachsenden Prozent dar. Die Unterschiede zwischen Mädchen und Jungen betreff Bullying/ Cyberbullying wurden in mehreren Studien in verschiedenen Ländern und Kulturen hervorgehoben. In dieser Studie haben wir aus der Gensicht die Vorstellungsform des Phänomens bei den Sekundarstufenschülern aus dem Kreis Muresch untersucht.Ausgangspunkt sind zwei Untersuchungen, die früher mit den Schülern der Sekundarstufe durchgeführt worden sind. Die Ergebnisse haben Unterschiede hinsichtlich der Rollen in Rahmen des Bullyindprozesses betont, Jungen sind eher agressiver/ belästigender als die Mädchen, aber es muss erwähnt werden, dass bedeutende Unterschiede in Bezug auf die Rolle des Mobbingsbelästigten nicht gefunden worden sind.

Bullying ist unter den Schülern der Sekundarstufe immer stärker, ohne einen riesigen Unterschied in Hinsicht auf das Schülergeschlecht.

\section{Introduction}

Bullying is the use of a higher force used in order to influence or intimidate someone (Olweus, 1993). Is repeated and intentional behavior where an abuser persecutes, injures, intimidates the victim verbally, relationally and/ or physically. This phenomenon occurs when a child is labeled, teased, threatened, ridiculed and given offensive replicas, and sexual comments are made against them in their group of acquaintances or colleagues. Sometimes these verbal conflict becomes physical attacks. Generally, the bullying manifested among boys is more visible than the one credited to girls. Manifestation of bullying in teenage girls is less visible, having a direct active and aggressive verbal behavior such as cursing, calling them names, direct or indirect threat, defamation (Soitu et al., 2001). This type of verbal violence affects the victim psychologically. In boys, violent behavior is visible, taking the form of physical aggression such as hitting the victim.

\section{Theoretical Foundation}

Research on bullying type behavior in school (Schott et al., 2017) can tell us how society can influence young people's behavior. The phenomenon of bullying occurs repeatedly over time, is initiated by one or more individuals and directed towards another, one that becomes the target of intimidation, unable to defend themselves in that context, the ratio of forces between the aggressor(s) and the victim(s) not being equal.

School violence is a complex phenomenon that exists in school communities in Romania, especially at secondary school 
level, which may affect the victim for a long time, sometimes their whole lives, through high levels of depression, anxiety or behavior problems. The consequences of this kind of bullying type aggressive behavior will lead to the isolation of target. Children affected by such aggressive behavior from their colleagues get a lower self-esteem, feel discouraged, do not want to go to school, sometimes become aggressive with themselves or with others. Approaching the phenomenon of bullying/ cyberbullying, based on sexual orientation and gender identity, it is important to be treated on levels of understanding, interest and by every age group. There are studies made in Ireland, showing the age of 11 and 12 being the one when some students begin to define themselves as having a different sexual orientation than most.

Targets of bullying are school students that are „different” from others, are believed to belong to groups or classes considered to be lower, such as children with limited financial possibilities, students with disabilities, children of other ethnicities. Violent behavior is not accepted, although it exists. Bullying/ cyberbullying is a tolerated phenomenon, being part of daily school life; this phenomenon can occur both inside and outside of school, through social networks, as cyberbullying.

With the staggering development of technology, also in our country, as in western countries, the problem of bullying in Romanian schools has worsened, becoming a wider problem, called cyberbullying. In schools in Romania we are beginners regarding detection and intervention in matters of cyberbullying. We heard that there is cyberbullying in other countries, but we do not know what to do with what we face in our schools. Some studies (Raskauskas \& Stoltz, 2007, Li, 2005) show that cyberbullying is an extension, a continuation of traditional bullying. But other studies (Green, 2006) let us believe that cyberbullying is different from traditional bullying because it overwrites some of its characteristics, such as the fact that in traditional bullying the victim knows the perpetrator, in traditional bullying there is a difference between the physical strength of the aggressor and the victim, and it takes place usually around or in schools.

Although there are some difficulties in creating a direct comparison, preliminary results indicate that the phenomenon of bullying and cyberbullying is more prevalent in the US than in European countries.

In a study by Save the Children Foundation in Romania, under the Helpline developed inside the Sigur.info project, within two years over 620 calls and complaints were received from both children and adults. Among the most serious problems reported are harassment and abuse on the Internet (209). Cyberbullying occurs in forms of verbal aggression, calumniation, stealing personal data. Romania is the country with the highest incidence of harassment in Europe in terms of cyberbullying and online abuse. EU Kids Online II study shows that $13 \%$ of children in Romania were harassed online, and $41 \%$ of children said to be harassed in any way. Of parents assessed across Europe, Romanians are those that mostly underestimate the risk of exposing their children to „sexting" type of messages, only $6 \%$ of them declare this happening to their children.
A study conducted by EU Kids Online in 2014 has shown that, compared to 2010, the occurrences of the cyberbullying type harassment has increased, among both girls and boys. If in 2010 the number of harassed boys and girls was similar, in 2014, the number of harassed girls is higher $(21 \%)$, compared to boys $(14 \%)$.

A fairly recent study in 2006, conducted by Quing Li, has shown that, of a number of 264 students surveyed, about half were victims of bullying, and one in four has been abused by the means of electronic communication. Half of the teens surveyed knew their abusers. The study also revealed a significant difference in behavior between the sexes, boys being more likely in the position of bully/ cyberbully type aggressors than girls. (40.8\% boys, $27.8 \%$ girls). Regarding the role of a victim in traditional bullying/ cyberbullying, boys and girls are victims in a very similar percentage (bullying girls: $44.4 \%$, boys $53.7 \%$ ).

Another study (Hoover et al., 1992) conducted in the USA shows that there was a quite large number of those who were victims of bullying or cyberbullying at some point during their adolescence. $72 \%$ of girls and $81 \%$ of boys have experienced a bullying type of aggression.

Several specialists (Keith et al., 2005) tell that girls are more likely to engage in cyberbullying than boys, teenager girls using verbal aggression frequently. These studies bring it to our attention that the gender difference is an important factor in understanding both the phenomenon of cyberbullying and the bullying type of aggression.

Thus, in this study we try to assess the phenomenon of bullying and cyberbullying among students from Mures, from a gender role perspective.

\section{Research methodology 3.1. Research design}

In this paper we analyzed the manifestation of the phenomenon of bullying and cyberbullying in the gender's perspective, in students of secondary schools in Mures county. In these studies have investigated generally how children understand both the interference (Smith et al., 2002) and the differences between the characteristics of the phenomena of harassment, aggression, bullying, cyberbullying, both in and outside school. Gender differences, regarding the aggressive behavior of bullying and cyberbullying were investigated in two separate studies. This study is both quantitative and correlational. I used Opinion Based Research Methods, during this study. I applied questionnaires to middle school students from Mures County in order to learn their experiences and attitudes towards the two phenomena, bullying and cyberbullying. The aim of this study was to evaluate the differences between girls and boys in terms of their behavior and their attitudes towards the two phenomena.

\subsection{Participants}

Traditional bullying was assessed in 107 students, aged 10-15. From a gender perspective, the total number of participants were males 56.1\% and females 43.9\%. Background: $60.7 \%$ urban and $39.3 \%$ rural. The research was conducted during September- 
November 2016, in schools of Mures County.

Table 1. Description of participants from the viewpoint of gender difference

\begin{tabular}{ccc}
\hline Number of participants & Percent & aria of residence \\
\hline 60 girls & $56,1 \%$ & $60.7 \%$ urban \\
\hline 47 boys & $43,9 \%$ & $39.3 \%$ rural \\
\hline
\end{tabular}

Cyberbullying and its ways of manifestation have been studied in a sample of 175 students, aged 10-15 years. From a gender perspective, the total number of participants were 91 males $(52 \%)$ and 84 females (48\%), background: $58.3 \%$ urban and $41.7 \%$ rural. The research took place in April 2017, during the crisis called „Blue Whale” in schools in Mures County.

Table 2. Description of participants from the viewpoint of gender difference

\begin{tabular}{lcl}
\hline Number of participants & Percent & aria of residence \\
\hline 91 girls & $52 \%$ & $58.3 \%$ urban \\
\hline 84 boys & $48 \%$ & $41.7 \%$ rural \\
\hline
\end{tabular}

The sampling was non-randomized, pseudorandomized or of convenience, using participants that were available. This situation was created by practical considerations. Participants were asked to respond in writing.

\subsection{Measures:}

This paper uses the results of two recent studies and highlights only the aspects that relate to gender differences. In the two studies were applied two questionnaires as the main source of data collection. A first questionnaire, applied to a number of 107 students, was aimed to assess traditional harassment regarding gender difference, the questionnaire containing 49 questions. We were interested in finding answers to the following questions:

- If the phenomenon of bullying is present in secondary schools in Mures County;

- What are the manifestations of this phenomenon in schools in Mures County;

- If there are differences in the phenomenon of bullying between girls and boys.

A second questionnaire that we applied targeted the phenomenon of cyberbullying and its forms of manifestation, destined for a target group of a number of 175 students, containing a number of 12 questions. We evaluated the forms of cyberbullying for boys and girls and the differences in roles of the victim and the aggressor between girls and boys.

For studying the bullying we have used questionnaires focused on the concept of bullying and cyberbullying, prepared by the CJRAE
Mures team. In terms of the type of questions of the questionnaire for assessing bullying we used both open-ended questions and halfopen-ended questions. The second questionnaire to assess the phenomenon of cyberbullying in schools we have only used closed-ended questions. For closed-ended questions we have used scales. Questions/ statements had answers on a scale from 1-5 (1very often, 2 - often, 3 - neither too often nor too rarely, 4 - rarely, 5 - never) participants choosing a number depending on their experience of traditional bullying and cyberbullying.

In present research we highlighted those aspects of the study that relate to the differences between girls and boys regarding the percentage and forms of manifestation of bullying and cyberbullying in Mures County Schools.

\subsection{Procedure:}

Both questionnaires were applied by psychologists in secondary schools in Mures county. We have chosen classes with average school results, students were selected from six secondary schools in both rural and urban areas. Questionnaires were completed in pencil by pupils in classes V, VI and VII.

Data from the questionnaires were processed quantitatively, using the statistical program SPSS22: descriptive analysis: percentage frequencies, bivariate correlations, open questions, they were processed through content analysis. In statistical analysis we used the simple correlation coefficient of Bravais-Pearson at a significance threshold of $p=<0.05$, Crosstabulation, Pearson Chi Squaret.

\section{Results}

The main objectives of this study was to determine the differences between girls and boys in terms of manifestations of traditional bullying and cyberbullying.

The presence of the phenomenon of bullying is highlighted and is present also in schools in Mures county, $65 \%$ of the surveyed children know the concept of bullying/ cyberbullying (describing it as aggressive behavior, intentionally shown by an older or stronger child, threatening, beating, contempting, cursing, hurting other children.) (Muresan \& Porkolab, 2016). According to statistics, the phenomenon of cyberbullying is present in schools in Mures County.

The manifestation and the frequency of the phenomenon is as follows: $6.3 \%$ of the respondents were often deliberately excluded by their colleagues/ friends from conversations on social networks. Offensive messages were received in the last two months via the Internet by $10.3 \%$ of respondents, and $8 \%$ of them were deliberately humiliated by posting videos or photos without their consent (Porkolab \& Mureşan \& Mihai, 2017).

In terms of gender differences on how students feel in school, the results showed that girls feel strained in terms of their general condition in school, and declare that they have fewer friends than boys. The girls feel tension and boys feel more sadness. 
Table 3. Case Processing Summary

\begin{tabular}{|c|c|c|c|c|c|c|}
\hline & \multicolumn{6}{|c|}{ Cases } \\
\hline & \multicolumn{2}{|c|}{ Valid } & \multicolumn{2}{|c|}{ Missing } & \multicolumn{2}{|c|}{ Total } \\
\hline & $\mathrm{N}$ & Percent & $\mathrm{N}$ & Percent & $\mathrm{N}$ & Percent \\
\hline GEN *Tension & 107 & $100,0 \%$ & 0 & $0,0 \%$ & 107 & $100,0 \%$ \\
\hline
\end{tabular}

Table 4. GEN * Tension Crosstabulation

\begin{tabular}{|c|c|c|c|c|c|}
\hline & & & \multicolumn{2}{|l|}{ Tension } & \multirow[b]{2}{*}{ Total } \\
\hline & & & 0 & 1 & \\
\hline \multirow[t]{10}{*}{ GEN } & Feminin & Count & 16 & 32 & 48 \\
\hline & & $\%$ within GEN & $33,3 \%$ & $66,7 \%$ & $100,0 \%$ \\
\hline & & $\%$ within tension & $32,7 \%$ & $55,2 \%$ & $44,9 \%$ \\
\hline & & $\%$ of Total & $15,0 \%$ & $29,9 \%$ & $44,9 \%$ \\
\hline & & Residual & $-6,0$ & 6,0 & \\
\hline & Masculin & Count & 33 & 26 & 59 \\
\hline & & $\%$ within GEN & $55,9 \%$ & $44,1 \%$ & $100,0 \%$ \\
\hline & & $\%$ within tension & $67,3 \%$ & $44,8 \%$ & $55,1 \%$ \\
\hline & & $\%$ of Total & $30,8 \%$ & $24,3 \%$ & $55,1 \%$ \\
\hline & & Residual & 6,0 & $-6,0$ & \\
\hline \multirow[t]{4}{*}{ Total } & & Count & 49 & 58 & 107 \\
\hline & & $\%$ within GEN & $45,8 \%$ & $54,2 \%$ & $100,0 \%$ \\
\hline & & $\%$ within tension & $100,0 \%$ & $100,0 \%$ & $100,0 \%$ \\
\hline & & $\%$ of Total & $45,8 \%$ & $54,2 \%$ & $100,0 \%$ \\
\hline
\end{tabular}

1= tension YES

0 =tension NO 
Table 5. Chi-Square Tests

Pearson Chi-Square

Continuity Correction ${ }^{b}$

Likelihood Ratio

Fisher's Exact Test

Linear-by-Linear Association

$\mathrm{N}$ of Valid Cases

\begin{tabular}{|r|r|r|r|r|} 
Value & Df & $\begin{array}{c}\text { Asymptotic } \\
\text { Significance } \\
\text { (2-sided) }\end{array}$ & Exact Sig. (2-sided) & Exact Sig. (1-sided) \\
\hline $\mathbf{5 , 4 4 5}$ & $\mathbf{1}$ & $\mathbf{, 0 2 0}$ & & \\
$\mathbf{4 , 5 7 3}$ & $\mathbf{1}$ & $\mathbf{, 0 3 2}$ & & \\
5,511 & 1 &, 019 & & \\
& & & & \\
5,394 & 1 &, 020 & & \\
107 & & & & \\
\end{tabular}

Table 6. GEN * sadness Crosstabulation

\begin{tabular}{|c|c|c|c|c|c|}
\hline & & & & & \\
\hline & & & $\mathrm{ml}$ & & \\
\hline & & & 0 & 1 & Total \\
\hline GEN & feminin & Count & 46 & 2 & 48 \\
\hline & & $\%$ within GEN & $95,8 \%$ & $4,2 \%$ & $100,0 \%$ \\
\hline & & $\%$ within sadness & $48,4 \%$ & $16,7 \%$ & $44,9 \%$ \\
\hline & & $\%$ of Total & $43,0 \%$ & $1,9 \%$ & $44,9 \%$ \\
\hline & masculin & Count & 49 & 10 & 59 \\
\hline & & $\%$ within GEN & $83,1 \%$ & $16,9 \%$ & $100,0 \%$ \\
\hline & & $\%$ within sadness & $51,6 \%$ & $83,3 \%$ & $55,1 \%$ \\
\hline & & $\%$ of Total & $45,8 \%$ & $9,3 \%$ & $55,1 \%$ \\
\hline Total & & Count & 95 & 12 & 107 \\
\hline & & $\%$ within GEN & $88,8 \%$ & $11,2 \%$ & $100,0 \%$ \\
\hline & & $\%$ within sadness & $100,0 \%$ & $100,0 \%$ & $100,0 \%$ \\
\hline & & $\%$ of Total & $88,8 \%$ & $11,2 \%$ & $100,0 \%$ \\
\hline
\end{tabular}

Table 7. Chi-Square Tests

\begin{tabular}{|c|c|c|c|c|}
\hline Value & $\mathrm{df}$ & $\begin{array}{c}\text { Asymptotic } \\
\text { Significance (2- } \\
\text { sided) }\end{array}$ & $\begin{array}{c}\text { Exact Sig. (2- } \\
\text { sided) }\end{array}$ & $\begin{array}{c}\text { Exact Sig. (1- } \\
\text { sided) }\end{array}$ \\
\hline $4,343^{\mathrm{a}}$ & 1 & 037 & \multirow{4}{*}{, 062} & \multirow{4}{*}{034} \\
\hline$\underline{\mathbf{3 , 1 5 4}}$ & $\underline{1}$ &, 076 & & \\
\hline 4,784 & 1 &, 029 & & \\
\hline $\begin{array}{r}4,303 \\
107\end{array}$ & 1 &, 038 & & \\
\hline
\end{tabular}

Table 8. Differences between girls and boys

\begin{tabular}{|c|c|c|c|}
\hline & $\begin{array}{l}\text { Pearson Chi- } \\
\text { Square }\end{array}$ & $\begin{array}{l}\text { Significance } \\
\text { (2-sided) }\end{array}$ & $\begin{array}{c}\text { Correction } \\
\text { Yates }\end{array}$ \\
\hline Gen vs. tension & 5,445 & .020 & .032 \\
\hline Gen vs. sadness & 4,343 & .037 & .076 \\
\hline
\end{tabular}

Regarding absences from school (ideal setting for harassment), boys absent (ditch) more often than girls.

Regarding the behavior of the bully/ abuser, boys show more often the following behaviors than girls: hit or knock another child, humiliate/ embarrass other children, spread rumors about other children, destroy things of other children if it upsets them, push and jostle other children. Regarding the behavior of the victim, boys are often ridiculed by peers than girls, and feel they do not get so 
many friendly behaviors from peers as the girls. The following behaviors were more often experienced by boys than by girls: to ask another child not to play with them, be threatened and hit by other children, be humiliated and ridiculed in public, to spread rumors about them, be beaten by other children.

Regarding interventions in cases of aggression, boys as well as girls agree that guards or other students interfere; teachers rarely do.
In the research on the phenomenon of cyberbullying, boys were more often victims of various fraudulent methods to obtain data, embarrassing information about them, which were later distributed online, but they were challenged more rarely to respond aggressively online than girls.

Table 9. Differences in experiences of online world between girls and boys

\begin{tabular}{|c|c|c|c|c|}
\hline & & & & \\
\hline & & $\begin{array}{l}\text { Personal information use by } \\
\text { other people }\end{array}$ & $\begin{array}{l}\text { Challenges to } \\
\text { aggressive behavior in } \\
\text { online environment }\end{array}$ & $\begin{array}{l}\text { Getting contacted by catfish } \\
\text { people }\end{array}$ \\
\hline Male & $\begin{array}{l}\text { Pearson Corelation } \\
\text { Sig. (2-tailed) } \\
\text { N }\end{array}$ & $\begin{array}{c}-.158^{*} \\
.040 \\
175\end{array}$ & $\begin{array}{l}-.006 \\
.936 \\
175\end{array}$ & $\begin{array}{l}.079 \\
.269 \\
175\end{array}$ \\
\hline Female & $\begin{array}{l}\text { Pearson Corelation } \\
\text { Sig. (2-tailed) } \\
\text { N }\end{array}$ & $\begin{array}{l}.282 * * \\
.000 \\
175\end{array}$ & $\begin{array}{l}.361 * * \\
.000 \\
175\end{array}$ & $\begin{array}{l}359 * * \\
.000 \\
175\end{array}$ \\
\hline
\end{tabular}

According to a study (Keith et al., 2005) girls tend to cause more severe aggressive acts online. But boys were more often contacted by catfish people (which claim to be someone who actually they are not).

\section{Discussion}

Regarding school bullying, according to our study, boys are slightly more exposed to it than girls, this depends also on which school they go to.

Regarding cyberbullying, girls and boys are exposed equally, identity of the bully or the victim may be hidden. The younger generation can easily be co-opted in misconduct in the virtual environment where there are no mental or moral limits or physical strength differences.

In 2016, the Child Helpline Association has registered more than 2,500 cases of bullying in Romania, most of the cases regarding physical violence, than verbal abuse, emotional abuse and relational abuse. Approximately $57 \%$ of the calls came from girls. Emotional bullying is more common among girls, while „physical bullying” is more present among boys.

Regarding the victims of the phenomenon, $43 \%$ of boys and $57 \%$ of girls have been victims of bullying worldwide, and $42 \%$ of boys and $58 \%$ of girls in Europe.

The problem is not the children's gender, it is more pressing that, in most European countries, over $50 \%$ of children are victims of bullying and cyberbullying. Prevention and intervention programs should be our future goals.

Girls being more empathetic can be one of the reasons why girls rarely get as aggressive as boys, empathy being a part of socialization in terms of gender (Rueckert \& Naybar, 2008).

From research conducted at secondary schools in Mures County is noted that the phenomenon of bullying is more common in girls than in boys. Therefore, we can say that it is both a fact, but may be a traditionalist approach related to mentality and education. In Romanian tradition, in our culture for boys ,being a man” means solving their own problems, hardly accepting help from those around him, family, teachers, counselor. Since education is implemented in partnership with parents, not only the school being accountable for prevention programs, the prevention and intervention must be carried out with the help of the parents so that they could learn to recognize manifestations/ symptoms of harassment their own children are subject of, in order to to fit their needs in crisis situations.

Both girls and boys frequently use social isolation as a method of intimidating the victim, by spreading different rumors using mocking words. So even though the child seems somewhat quietly withdrawn from school social life, behind that calm there can be a whole process of bullying.

The phenomenon of bullying that occurs in adolescence, if not halted by intervention programs, may create the premises of an aggressive bullying during adulthood, where victims can become perpetrators or remain in the role of a victim, being exploited by colleagues/ bosses at their working place. It can be said that the phenomenon of bullying can become a major social phenomenon that must be properly treated by specialists, since the first signs of its onset, during childhood.

Studies in Romania aimed to follow the presence of cyberbullying among young people, have shown that it exists in our midst, requiring the specialists intervention in order to curb its negative effects. New studies in Mures county has proved the existence of cyberbulying among secondary school students, both in urban and in rural areas. Students' responses to questions applied through questionnaires show that students know the two phenomena of bullying and cyberbullying. It is important to continue studying ways of manifestation of the two phenomena among secondary school students, the way how social networks become dangerous when students become aggressive with each other. The study showed gender differences, meaning that girls are more aggressive than boys.

\section{Conclusions}

Bullying as a method of intimidation will take more and more the form of cyberbullying, because young people spend more and more time online, and interact less and less with each other in the physical environment (girls tend to have fewer and fewer friends in 
the real world), and all more in the virtual environment, students saying they have more virtual friends than real.

The main conclusion of this study was that boys tend to be more aggressive directly, and were attacked, witnesses and victims of school bullying more often than girls. In some studies (Lagerspetz, 1988) noted that girls have used more indirect means of aggression, while boys tended to use direct means. Gender differences in verbal aggression were less pronounced. The social structure of peer groups was considered stricter among girls, thus facilitating the exploration of relations and injuring their victims by the indirect aggression of manipulation.

The phenomenon is alarming. Preteens are in a very fragile phase of personality development, they are very impressionable,

\section{References}

Hoover, J.H, Oliver, R., Hazler, R.J. (1992). Bullying: Perceptions of Adolescent Victims in the Midwestern USA. pp. 5-16.

Keith, S., Martin M. E. (2005). Cyber-bullying: Creating a Culture of Respect in a Cyber World. Reclaiming Children and Youth 13 (4): 224-8.

Lagerspetz, Kirsti, M. J., Björkqvist, K., Peltonen, T. (1988). Is indirect aggression typical of females? Gender differences in aggressiveness in 11-to 12-year-old children. Aggressive behavior14.6 (1988): $403-$ 414.

Li, Q. (2005). New Bottle but Old Wine: A Research of Cyberbullying in Schools. Computers in Human Behavior 23: 1777-91.

Li, Q. (2006). Cyberbullying in Schools A Research of Gender Differences. School psychology.

Albulescu, I. et al. (2016). Education, Religion, Family in the contemporary society. Lambert, pg. 263-273.

Olweus, D. (1993). Bullying at school: What we know and what we can do. Oxford, UK: Blackwell.

Porkolab A., Mureșan L., Mihai A. (2017). Rolul educației în dezvoltarea identității culturale ale elevilor, Conferință Națională cu participare Internațională, Editura University Press, Tîrgu Mureș, pg. 132-136. and cyberspace effects can cause more severe trauma than the emotions and direct interactions with others.

As teachers and parents, we must make a stand, to know the best methods and modalities of the phenomenon's manifestations, so we could be a real support for a problem as ,real” as cyberbullying can be for the preteens of online environment.

Raskauskas, J., Stoltz, A.D. (2007). Involvement in Traditional and Electronic Bullying among Adolescent. Developmental Psychology 43(3): 564-73.

Rueckert, L. \& Naybar, N. (2008). Gender differences in empathy: The role of the right hemisphere. Brain and Cognition, 67, 162-167, doi: 10.1016/j.bandc. 2008.01.002.

Schott, R. M., Søndergaard, D. M. (2014). School Bullying - New Theories in Context. Cambridge University Press, pp. 21-22.

Smith, P. K. et al. (2002). Definitions of bullying: A comparison of terms used, and age and gender differences, in a Fourteen-Country international comparison. Child development 73.4 (2002): 11191133.

Șoitu, L., Hăvârneanu, C., Neamțu, C. (2001). Aggression in school, Institutul European. pp. 21.

http://www.sigur.info/docs/resursa-cyberbullying.pdf.

http://salvaticopiii.ro/upload/p000600010001_Salvati\%20Copiii_Rap ort\%20bullying.pdf.

http://www.Ise.ac.uk/media@Ise/research/EUKidsOnline/EU\%20Kid s\%200nline\%20reports.aspx.

http://www.telefonulcopilului.ro/. 